\title{
Inherent Presence Of Children In Society "Proposed Criteria And Indicators."
}

\author{
${ }^{1}$ Nermeen Singer, ${ }^{2}$ El Farahaty Elsayed \\ ${ }^{1}$ Associate Professor of Media \& Child Culture, Faculty of graduate Childhood Studies \\ Ain Shams University - Nermin.singer@chi.asu.edu.eg - ORCID: https://orcid.org/0000-0002-4913-4523 \\ ${ }^{2}$ Professor of Psychology - National Center of examination \\ Ministry of Education.
}

Article History:Received:11 January 2021; Accepted: 27 February 2021; Published online: 5 April 2021

\begin{abstract}
This study shows that achieving the child's inherent presence is a vital requirement for a life he deserves, as the child's inherent existence is the extent to which the child gets a sense of satisfaction with life. This is according to key components such as integration in mutual relationships and opportunities to develop life skills and develop children's right to express their views and create a healthy and child-friendly climate.

The research supports enabling early childhood professionals to work together with children's families to achieve common outcomes for all children. Promote all learning and development outcomes. The results confirm the importance of sensitive practice and responding to children's desires and need to support their real presence in society.

The study resulted in indicators and practices carried out by the child and his teachers in all five areas of the feeling of original existence which are developing children's strong sense of identity, developing children's connection to and participation in their world, improving children's sense of personal happiness, development and improvement of self-confidence in children, and developing and refining effective dialogue with children.

The novelty of the study is shown from the achieving the child's original existence is a vital requirement for a life he deserves, as the child's original presence is that extent to which the child gets a sense of satisfaction with life according to key ingredients such as integration in mutual relationships and opportunities to develop life skills and develop children's right to express their own views Create a healthy environment for children.
\end{abstract}

Keywords: children, develop, healthy, inherent, skills, society.

\section{INTRODUCTION}

Over the decades, the main focus was on raising living standards by increasing economic growth and employment. The time has come to focus not only on the gross domestic product, but on the inherent presence of the individuals in life, and that the measurement of the inherent presence of individuals is impossible with money or trade in the markets. This inherent existence relates to the beauty of our surroundings, quality of culture, and the strength of relationships as well.

I believe that improving our society's sense of its inherent existence is the central political challenge of our time, and we must focus on children as they constitute more than a quarter of the population of the Arab Republic of Egypt.

The study of the inherent existence of children is associated with important considerations, including what has been confirmed by developmental psychology research that a large part of the child's cognitive, linguistic, and social development takes place during the first years of life. What the theories of psychological development of children emphasized on the necessity of stimulating the child's senses and making him perform the most significant possible activities during the first years of his life to achieve his proper development. What Vigotski emphasized is that the child is born with Proximal Development capabilities, and the existence of a more knowledgeable and experienced cultural mediator brings the child to the maximum of his skills and what he can. Furthermore, What the results of many studies revealed is that any neglect or deprivation of the child in early stages has long-term effects on his development in all its aspects unless appropriate. The implementations of early compensatory programs are possible so that their care comes close to their protection and immunization and avoiding them from suffering from the complications of neglecting their own needs.

It is the time for children to have more significant opportunities to develop the neuropsychological pathways for learning and to build up stocks of their mental, psychological, physical, emotional, and spiritual development in the future (Bouchard et al., 2009).

Early experiences and relationships affect children in the long term, with the presence of safe and saturated relationships that make them discover themselves and the world around them.

In this way, the children resemble the young scientists as they discover everything that falls in their hands and put it directly into their mouths and frequently ask, what will happen if I catch this or throw the game over there or press the red button? Or or...? The role of the educator is to create a safe base from which the child starts to 
discover and take support; therefore, the feelings of confidence and competence are tended to grow (Edwards \& Cutter-Mackenzie, 2011).

Our research highlights the priorities for improving the better presence of our children. This report identifies each priority and explains the reason beyond such importance for children and families together with providing advice to decision-makers in evaluating what the child and early childhood teachers are doing to achieve the inherent existence of children, in a way that helps in making our country a place where every child can aspire to a good childhood.

1.1. Hypothesis:

H1: Study the concept of the inherent presence in society.

$\mathrm{H} 2$ : Investigate the imbalance factors of inherent presence in society.

H3: Present the proposed components for the roles of the child and early childhood teacher to achieve the inherent presence of children.

\section{LITERATURE REVIEW}

Monitoring the inherent presence of children is essential for the realization of their rights following the United Nations Convention on the Rights of the Child (UNCRC, 1989), and is crucial for interpreting the best interests (Article 3) and promotion the child's mental, spiritual, moral and social development (Article 27 regarding providing an adequate standard of living) and Article 32 (regarding protection Children from harmful work) and Article 24 concerning the (right to health) and Articles 28 and 29 concerning the (the right to education), Article 31 concerning the (rights to play and recreation), Articles 5 and 18 concerning the (parents' responsibilities) and affirm the child's right to realize his full potential and participate in decisions that affect his life.

The World Health Organization described the child's positive condition according to the definition of health as "a complete state of the child's inherent presence in the physical, mental and social terms and not merely the absence.

UNICEF emphasizes the responsibility to defend the protection of children's rights, meet their basic needs and expand their opportunities to reach their full potential". In addition, the four learning pillars according to UNESCO's 1996 report on that learning report, which is the treasury are namely: Learn to Work and Learn to Be, Learn to Live Together and Learn Knowledge and Learn as a Process.

The inherent presence is a universal human right that includes the bliss of the individual, society, and the world and extends for future generations (Pollard \& Lee2003).

The inherent presence is the realization of the unique potential of the individual through physical, mental, emotional, and spiritual development in relation to oneself, others, and the environment. The development of the individual is essential to his inherent presence, and this is possible through participation with the world around us and our meaningful relationships (O'Toole, 2014).

Childhood is limited to years from birth to twelve and includes the first two years and early childhood from 35/6 years while the middle childhood from 6-9 years and the late childhood from 10-12 years, bearing in mind that there are no definite borders between these stages, as they are overlapped with each other in a development sequence from one stage to another as much as cultural, environmental and social stimulation factors influence in making a qualitative shift from one stage to another. (Singer,2019).

As a result of the length of this stage, the child's physical, mental, emotional, and social characteristics change, and the essential characteristic of childhood is its dependence on others to provide for this stage's needs (Lang, 1995). A person may be amazed if he knows how many creative ideas and possibilities are wasted due to the inadequacy and ignorance of social institutions by the methods of the inherent presence of children, and how many inimitable geniuses whose features have become blurred or deviated from their course due to society's neglect of them. (Singer et al., 2019)

The process of the inherent presence of children starts through methods of transforming the individual into a member of society that acquires knowledge, skills, habits, attitudes, and values that extend his presence in society.

\subsection{Definition of the inherent existence of children:}

The child, by his instinct, is prepared to receive his development experiences from the socio-cultural reality, which means that the child does not grow and his inherent presence is possible only if he integrates into an educational process that takes into account the laws of his development as a natural right of the child, and that the exercise of this right is a realization of his inherent presence.

The inherent presence of the child relates to providing each child with the opportunity to be all that he can be in light of the child's abilities and capabilities, and this is according to the positive results of the children (Bradshaw et al.,2007).

The inherent presence of the child has become an integral part of academic and political discourse in recent years, as evidenced by an increasing number of publications, magazines, and conferences relating to the inherent presence of the child (Sointu, 2005; Corsin-Jimenez et al.,2007). 
The inherent presence is a real human presence that is not achieved on its own, but it is achieved by instinct and experience according to the interaction of potential capabilities in children and a civilized experience transferred by society to them and rights through the education institutions and the learning and culture media and the included stimulation of the child potentials.

The inherent presence is not a one-sided process, rather a reciprocal process in which all are integrated into a unique, progressive human experience open to all parties and elements of that experience (Edwards \& CutterMackenzie, 2011) and the inherent presence of the individual is a concept influenced by the health of the individual, his psychological state, social relationships, his independence and relationship to his environment (Evangelou, Brooks \& Smith, 2007).

The inherent presence of children comes from the sense of meaning of their lives and an appreciation of goals and values for the future. This is evident in the fact that children define success by the sense of happiness, achieving goals, positivity, excellent performance in the family and school, providing assistance to others, and spending free time (Goleman, 2012).

Self-Actualization Values, Philanthropy, Philanthropy, and Connectedness, are inherent in the depths of the children's world and should be focused on and invested in the family, school and the media (Evangelou, Brooks \& Smith, 2007).

The inherent presence means that level at which a child obtains a sense of satisfaction with life, including the integration in mutual personal relationships, opportunities for personal development such as developing life skills, exercising rights and making choices based on the child's way of life (Hill \& Taylor, 2004).

\subsection{The family realizes the inherent presence of the child in society}

The family is a major social institution, the site of many social activities of the individual and a social unit that was prepared through marriage and is nuclear (parents and children) or extended (in addition to other relatives) and the family is a basic unit that provides love, and appropriate material gratification and children learn to respect and practice the values of society. (Singer \& El-Sayed Mahmoud, 2020)

There is a large proportion of families that are not familiar with the methods of achieving the inherent presence of children and that the methods of upbringing may be subject to the emotions of adults and their needs, and methods of oppression and subjugation depend on the transfer of culture to the child without regard to the child's personal initiatives. Rather, it pours the child into pre-traditional ideas and reproduces predetermined human patterns. And a duplicate image of the parents who are in turn a duplicate image of those who preceded them (social cloning), and this leads to the reproduction of children and their behavioral formation without taking into account their natural attributes. (Shonkoff \& Meisels, 2011)

The child is subject to a dual subjection and domination, submission to whoever is within the scope of his behavior, and domination is for whom is in the scope of our disposal, and such a mechanism constitutes a transformation relationship because it is abnormal at the time when the inherent adaptation presence is a must as a method that cares about the spontaneity of dealing with children and developing their capabilities in fruitful ways (Singer,2019).

The upbringing institutions are turned into compulsory, subjective ones that do not provide the opportunity for the child's potential to be freed from their potentials, and, in their manner, seek to convert them into repressions that lead to a contract embodied in the form of deviant behavior. Hence the upbringing institutions are transferred from institutions of formation and development to institutions of molding and reproduction (Singer,2019).

We should take into account the natural determinants and psychological preparations in terms of the inclinations, interests and preparations in case that the child is to be normal in the sense that the child's development process has physical, mental, emotional and social dimensions based on a premise that a person is an organism/social psyche.

Hence, the process of inherent presence is the embodiment of a state of interaction between environmental and natural determinants (self and society), and from their interactions, the child grows, and his behavior is determined Each institution works to impose its obligations on the child in a way that is characterized by compulsion and coercion, to the point of oppression by taming the child to respond to its demands within what we might call suppression, making him over the days to satisfy and accept this suppression as a result of repetition and exposure, especially since the child is in the early stages of life is unable to satisfy his psychological, social and biological needs by himself, which makes him subject to the orders and obligations dictated to him, which leads to the abandonment of his needs which seem urgent, but he is unable to satisfy it and suppresses it, therefore at that time he becomes submissive and has no power to object, reject or rebel (Singer,2019).

The matter did not lead the child to be submissive, but it forced him to give up as a result of putting pressure on him for much of what is a reflection of what Nature presented with its contempt and underestimation.

At a later stage, the child becomes responsive by taming to the orders and prohibitions imposed on him by the society institutions and with what he finds himself responsive through social inspiration, obedient and 
compelled in light of what the society says and its culture, and such leads to institutionalized legalization (Evangelou, Brooks \& Smith, 2007).

The individual may begin to exert pressure and coercion upon those in his circle of control within the family. That is, it becomes a reflection of the Nature of the society - with the culture - in which is living and that is, it has been molded.

We call this mechanism a subjugation, normalization, subjugation, subservience, compelling and molding, and this is how the circular loop continues. For example, adopting the method of insulting and beating in childhood is partly responsible for generating a violent society in old age, and the wrong behavior of the child is a reaction to the behavior of parents to draw attention by causing self-harm (Edwards \& Cutter-Mackenzie, 2011)

Some results showed that parents' behavior towards their children during the first five years was a direct or indirect cause of a child's personality disorder by not satisfying their needs at that time such as the family teaches the child to comply and submit in the event of the existence of authority, and the lack of compliance in its absence (fearful, not desirable). Furthermore, the child's dependency, impotence, evasion and cohesion are due to the authoritarian style prevailing in the family (Stamopoulos, 2012).

The suppression of spontaneous feelings and impeding individual growth begins in the early stages of raising a child, and studies of children's behavior through the use of a Rorschach test revealed an early conflict between spontaneous feelings of children and adult authority. This does not mean, of course, that education or training necessarily eliminates the spontaneous and automatic impulses of a child.

Education may prevent all of this if it aims to support and expand the area of internal independence and the independent attitude of the child, and in this way, it guarantees its normal development, unity of personality, and realization of its inherent presence in its society. However, the context surrounding the child often tends to eliminate automatic spontaneity in the child; and tends to compensate for the inherent psychological actions with feelings, ideas, and desires acceptable to others (Evangelou, Brooks \& Smith, 2007). Among the factors of imbalance of the child's inherent presence are the following models:

\section{2.a Knowledge-based on isolated facts or sporadic information}

When we put in the mind of the child hundreds or even thousands of unconnected information, we drain his time and energy in an automated effort that leaves him no chance to think. Fragmented information prevents correct thinking. It destroys every kind of possession of the complex image of the world in the mind of the individual.

The facts gain their value from being parts of each compound. If they are separable from this whole compound, they lose their power to act in the mind of the individual in order to absorb the world. Then every fact becomes just a piece of information linking to the rest of the facts, and this is what textbooks rely on now, and the media donates it now (Edgar, D., \& Edgar, P.,2008).

\section{2.b Incapacitation of the child's mind}

By assuring to the child that the problems are above their level of awareness now, and they are more complicated than being aware of them, and he must wait until they reach their level of awareness. This occurs at a time when these problems are so simple that everyone can understand them.

This child's incapacity method often results from one of two types of behavior.

A state of irony and skepticism about everything said or printed. Doubts about the usefulness of everything he knows.

- $\quad$ Failure to make decisions and leave that to others, i.e., waive the exercise of the will.

\section{2.c Falsification of the will}

People enter a race with each other, and sometimes with themselves in order to develop material possessions and young people imitate them in that, so they embrace the values of adults without questioning the extent of their needs to what they develop from, whereby televised means of advertising play a distant role in finding consumption illusions for individuals. Great men only drink such-and-such coffee, and bright women use this perfume. A successful businessman shaves with such blades.

The ordinary man and the ordinary woman think that they will become great ones if they drink the such-andsuch coffee or perfume, as the old lady thinks that using the season's fashion will return her to the ranks of elegant young women, they want what they really do not want but want the presentation to them at the will of others, so they embrace it as their own will, while they are weak-willed. This is what schools do, too. Look at what children have learned from songs and slogans across the entire Arab world, and you want an organized action to take away the will of the child and push him to convince what if he is left free, he will not be convinced of it. You see how the humanity of the child surrounded whether an individual or a personal entity.

\section{2.d Reducing the value of human emotions and the absolute emphasis on rationality}

The heads of children are fond of curiosity because they want to possess it physically and mentally. They want to know the truth because that is the safest way and a guarantee of being in a strange and powerful world that 
surrounds them. Instead of meeting their motivations, they are faced with derision or ignorance of their ideas (Ishimine \& Tayler, 2014).

One of the downsides of this method is that it implants in children a sense of betrayal when they grow up and discover that school taught them what the world denies or belies reality. What does the mother answer to her first child when he asks her where he came from? Or how the second child who is still in her womb is formed? This is one example, and there are many other more complex examples.

The mother who has the greatest burden in the process of confirming the inherent presence, we find that she focuses on what drives children to feel the false presence, not the inherent presence in the social environment:

- Fear of punishment, rather than guilt.

- Outward-oriented hostility as a means of emotional decompression, rather than enhancing self-confidence.

- Individualism rather than collectivism.

- Confirming aggression by taking revenge rather than cooperation and a sense of help.

- Confirming the obedience and submission instead of proactivity and initiative.

- Embodiment of the unseen forces of a child by intimidating him from unknown evil forces that are still not present in our minds.

- Destroying self-confidence rather than instilling and embedding it.

Achievement of the childhood means developing children according to the criteria of human development, which are necessary criteria compatible with their human Nature, which society discovers and is keen to develop it as a living reality through a life they deserve and is being entitled to.

\section{2.e Lack of respect for the diversity of children}

Lack of respect for diversity means a lack or imbalance of appreciation of family practices, values and beliefs (the history, culture, language, traditions, and lifestyle of children in their families, appreciation of children's differing preparations and respect for diversity) (Hill \& Taylor, 2004) when childhood teachers respect diversity, estimate family aspirations, and support children's rights, and they can then embrace children's motivation to learn and support their sense of being capable children.

Teachers create opportunities that take into account diversity, appreciate children's learning opportunities, respect their independence, learn to live together, and respect the culture of children's diversity (Lang, 1995).

Children should be represented in influential bodies and institutions in society in which opportunities to influence these entities are provided by listening to them in legislation, policies, plans, services and providing feedback on the quality and availability of public services provided to children (Edwards \& Cutter-Mackenzie, 2011). exercising their right to create forums dealing with their affairs and communicating their messages and desires to the stakeholders in society. Moreover, they have enough space to use the media to communicate their views to officials and public opinion (Hill \& Taylor, 2004).

The teachers resort to enhancing children's cultural merit, which is the ability to understand, communicate, and interact effectively with people across cultures in line with developing positive trends towards cultural diversity, gaining knowledge related to different cultural practices and world opinions and developing the skill for crosscultural communication and interaction.

\section{2.f Impaired response to children}

Teachers respond to children's skills, knowledge, and desires, as they value and develop them. They respond to the culture, knowledge, and multiple languages they speak, as well as to the methods of children with special needs (Ishimine \& Tayler, 2014). They also respond to the ideas and means of playing, the evolving ideas and desires of children and teachers evaluate, expect and expand the field of children's learning by asking open questions and by providing notes and challenging the way they think, and guiding the way of their learning, then they benefit from automatic "learning moments" in order to build and refine the learning process of children (Hill \& Taylor, 2004)

In this regard, responsive learning relationships are strengthened when teachers and children learn together, and when they share decisions, respect, and trust. Responsiveness enables teachers to act with respect to children's play, ongoing projects, stimulate their thinking, and enhance their learning (State Library Victoria 2015).

\section{METHODOLOGY}

The research methodology is according to the systematic steps, namely:

Study the literature on the inherent presence of children in society.

- $\quad$ Draw the components of the children's inherent presence in society from the analysis of the literature.
- $\quad$ Prepare proposed standards for the inherent presence of children in society to be activated by the child and early childhood specialists.

\section{RESULTS/FINDINGS}

The results revealed that there are components for the inherent presence of children, namely: 


\subsection{The first result: developing a strong sense of identity for children}

Children build their identity through their relationships with others, places, things, and other people's reactions, positive interactions with them, helping them, assessing their independence, and supporting their discovery and knowledge aspiration.

Identity is unique to everyone who determines who he is, and what constitutes his interests? How do I belong? What is my influence? How do others see me, and how do they communicate with me? It comes from the sense of security in social settings (family, community, schools) and then with interested adults and other children in places where they spend their time (State Library Victoria 2015). When children feel safe, their confidence grows for exclusion, knowledge curiosity, a sense of happiness, and awareness of its social and cultural heritage. He uses his native language (Elliott \& Young, 2015).

Affection is to consider adults as a source of comfort and reassurance to children through their interest, friendliness, consistency in their dealings, and their material and moral presence in children's lives. When children have positive attachment experiences, they develop a strong sense of identity, build a positive image of themselves, and act as safe, important, and respectful individuals (State Library Victoria 2015).

Safe relationships are determined by listening to children, considering their own vision, and providing a childfriendly learning environment that integrates them into decision-making processes consistent with their evolving capacities. Participate in community activities such as planning parks, clubs, commercial markets, roads, protecting the environment, and appreciating their protests about their awareness of the presence of harm to their environment or society.

Acquiring and maintaining local languages plays an important role in building identity. Early childhood specialists respect children's cultures and their languages through opportunities that strengthen their abilities, respect their cultural diversity, support their shared values, and embrace their social cohesion (Elliott \& Young, 2015).

In school settings, children have opportunities to learn the language, and for some children, this may be an opportunity to continue their first language, and for others, it is an opportunity to learn a new language.

Learning environments are welcoming and exciting places when they reflect the identity of children and responds to their desires and needs. In addition, learning environments are flexible as they are responsive to each child's desires and abilities (State Library Victoria 2015).

As children learn, they build on collaborative work, ask questions, and face new challenges. Planning to learn and hope for their accomplishments, recognize the value of perseverance, and enjoy their accomplishments.

All children with support can develop a strong sense of self and learn to interact with others with care, sympathy, and respect (Edwards \& Cutter Mackenzie, 2011).

The following are indicators of self-identity and child and teacher practices that develop these indicators:

\begin{tabular}{|c|c|c|c|}
\hline \multirow{2}{*}{$\begin{array}{l}\text { Outcome } \\
\text { Children have a } \\
\text { strong sense of } \\
\text { self-identity }\end{array}$} & Indicators & Child practices & Teacher practices \\
\hline & $\begin{array}{l}\text { Children feel safe, } \\
\text { secure and support }\end{array}$ & $\begin{array}{l}\text { The child maintains } \\
\text { relationships based on respect } \\
\text { and trust with others. } \\
\text { Expresses his feelings and } \\
\text { thoughts publicly in his } \\
\text { dealings with others. } \\
\text { Interacts and speaks with } \\
\text { teachers who trust him }\end{array}$ & $\begin{array}{l}\text { It responds to children's signals, } \\
\text { attempts, and effort in a meaningful } \\
\text { way. } \\
\text { Supports children through warm } \\
\text { and safe relationships, especially in } \\
\text { times of hardship and adversity. } \\
\text { Communicates with children } \\
\text { emotionally, enhances their } \\
\text { expression of their thoughts and } \\
\text { feelings, and recognizes the } \\
\text { uniqueness of each child }\end{array}$ \\
\hline & $\begin{array}{l}\text { Children's } \\
\text { independence and a } \\
\text { sense of control }\end{array}$ & $\begin{array}{l}\text { Understand the needs and } \\
\text { rights of others } \\
\text { Accept and understand new } \\
\text { challenges } \\
\text { Collaborate increasingly and } \\
\text { integrally with others. } \\
\text { Take a calculated risk towards } \\
\text { being able to deal with the } \\
\text { unexpected matters. } \\
\text { feel his individual } \\
\text { accomplishments as well as } \\
\text { those of others. } \\
\text { Estimate the value of }\end{array}$ & $\begin{array}{l}\text { Provides the child with ways to } \\
\text { make informed decisions about } \\
\text { their behavior in a way that } \\
\text { supports their sense of belonging. } \\
\text { Provides high expectations for each } \\
\text { child's capabilities separately. } \\
\text { Encourages children to negotiate to } \\
\text { know their rights and obligations. } \\
\text { Provides opportunities for children } \\
\text { to support their independence in } \\
\text { inappropriate activities for them. } \\
\text { Supports children's efforts, helps } \\
\text { and encourages them whenever }\end{array}$ \\
\hline
\end{tabular}




\begin{tabular}{|c|c|c|}
\hline & $\begin{array}{l}\text { negotiation and cooperation } \\
\text { with others. }\end{array}$ & necessary \\
\hline $\begin{array}{lr}\text { Children develop } \\
\text { self-identity } & \text { with } \\
\text { knowledge } & \text { and } \\
\text { confidence } & \end{array}$ & $\begin{array}{l}\text { He felt respected and accepted } \\
\text { by others. } \\
\text { Discovers different identities } \\
\text { and points of view through } \\
\text { games and activities. } \\
\text { Respects the culture of other } \\
\text { children and teachers. } \\
\text { He uses his mother tongue and } \\
\text { appreciates the culture and } \\
\text { language of his family and } \\
\text { society. } \\
\text { They respect and develop their } \\
\text { social and cultural heritage } \\
\text { through their interaction with } \\
\text { elders and members of } \\
\text { society. } \\
\text { Contact and communicate for } \\
\text { comfort, assistance, and } \\
\text { companionship. }\end{array}$ & $\begin{array}{l}\text { Children are encouraged to form } \\
\text { their own being and attach } \\
\text { themselves to others. } \\
\text { It respects cultural diversity and } \\
\text { acknowledges the differences } \\
\text { between children, families, } \\
\text { societies, and cultures. } \\
\text { Understanding the access of } \\
\text { children to the meaning in many } \\
\text { different ways. } \\
\text { He benefits from the knowledge, } \\
\text { languages, and } \\
\text { understanding that } \\
\text { themselves have. } \\
\text { It talks to children in respectful } \\
\text { ways about the similarities and } \\
\text { differences between people. } \\
\text { It provides ongoing support and } \\
\text { maintains the mother tongue and } \\
\text { the child's own culture. }\end{array}$ \\
\hline $\begin{array}{l}\text { Interacting with } \\
\text { others with care, } \\
\text { sympathy, and } \\
\text { respect }\end{array}$ & $\begin{array}{l}\text { Shows interest in other } \\
\text { children regardless of their } \\
\text { identity and ethnicity. } \\
\text { Expresses a variety of } \\
\text { emotions, ideas, and opinions } \\
\text { in a constructive way. } \\
\text { Empathizes with and } \\
\text { expresses concern for others. } \\
\text { Understands, respects, and } \\
\text { values others' points of view }\end{array}$ & $\begin{array}{l}\text { Caring for bilateral interaction with } \\
\text { children during the daily routine. } \\
\text { Organizing learning environments } \\
\text { in ways that enhance interaction in } \\
\text { small groups and obtain } \\
\text { experiences during play. } \\
\text { It takes care and respects other } \\
\text { children, teachers, and families of } \\
\text { children. a role model in } \\
\text { Being and social } \\
\text { communication and } \\
\text { experiences in ways that maintain } \\
\text { productive relationships with other } \\
\text { children. }\end{array}$ \\
\hline
\end{tabular}

\subsection{The second result: Association of children with and participating in their world}

From birth, children try to coexist with others and establish positive relationships that enhance their interests, accept their own uniqueness and the uniqueness of others, learn to participate in their world and society, exercise their active membership in their societies, learn to respect those who differ from them and practice peaceful and wise ways to resolve their disputes and understand fair play and how to be wise members of their groups.

They test their responsibilities and rights - and the rights of others - in familiar environments such as their families, playgroups, in the classroom, playgrounds, and friendship groups (Elliott \& Young, 2015).

Children should be seen as citizens equal in rights and should be consulted purposefully on issues that affect them. Consultation with children to understand their traditions and cultural and daily routine supports their participation in their societies, and contribute positively to their world. This is an enrichment that the essence of inherent existence is, for the most part dependent on will, volunteerism, and choice, not compulsion (Elliott \& Young, 2015).

Some children need experiences that emphasize the value of their belonging and facilitate their participation in community experiences. Some may need explicit guidance and support to help them feel safe. The note closely shows signals from the child to adults about the best way to help the child communicate and contribute to their world effectively (Elliott \& Young, 2015).

Under five-aged children communicate with their peers through initiatives such as presenting doll to a child who is crying or welcoming a new child with enthusiasm. Older children show interest in treating others with them and caring for friendships (Elliott \& Young, 2015). When children participate in daily routines, events, experiences, and decisions, they learn and coexist with others.

The following are indicators that children relate to, and participate in, their world and the child and teacher practices that develop these indicators: 


\begin{tabular}{|c|c|c|c|}
\hline Outcome & Indicators & Child practices & Teacher practices \\
\hline \multirow[t]{4}{*}{$\begin{array}{l}\text { Children } \\
\text { connect and } \\
\text { participate in } \\
\text { their world }\end{array}$} & $\begin{array}{l}\text { Children's sense of } \\
\text { belonging to their } \\
\text { world and developing } \\
\text { the concept of mutual } \\
\text { rights } \\
\text { responsibilities and } \\
\text { effective for } \\
\text { meaningful and } \\
\text { participation. }\end{array}$ & $\begin{array}{l}\text { Children know their right to } \\
\text { belong to many societies, to } \\
\text { participate with others, and to } \\
\text { negotiate roles and relationships } \\
\text { in activities group. } \\
\text { Children gradually perceive } \\
\text { other people's behaviors and } \\
\text { treat them appropriately. } \\
\text { Respond positively to others } \\
\text { and make appropriate and } \\
\text { meaningful friendships }\end{array}$ & $\begin{array}{l}\text { Support a sense of community } \\
\text { Provide opportunities for } \\
\text { children to search for complex } \\
\text { ideas, concepts, and ethical } \\
\text { issues related to their lives and } \\
\text { communities. } \\
\text { Use language that makes } \\
\text { children express their ideas to } \\
\text { negotiate roles and collaborate } \\
\text { to achieve goals. } \\
\text { Children have the skills to } \\
\text { participate in group } \\
\text { performances and joint } \\
\text { activities. }\end{array}$ \\
\hline & $\begin{array}{l}\text { Children respond to } \\
\text { diversity with respect }\end{array}$ & $\begin{array}{l}\text { They show interest in others and } \\
\text { discover cultural diversity, } \\
\text { heritage, and traditions in a way } \\
\text { that provides opportunities for } \\
\text { new choices and new } \\
\text { understanding. } \\
\text { Understand the similarities and } \\
\text { differences between individuals. } \\
\text { He listens to other people's ideas } \\
\text { and respects the different ways } \\
\text { of their identity and the way } \\
\text { they do things. } \\
\text { practices more comprehensive } \\
\text { approaches to achieving } \\
\text { equitable coexistence with other } \\
\text { children. }\end{array}$ & $\begin{array}{l}\text { He reflects on his approach to } \\
\text { diversity and plans to find } \\
\text { appropriate experiences and } \\
\text { resources to expand children's } \\
\text { horizons. } \\
\text { Show children different } \\
\text { languages and dialects. } \\
\text { Encourage children to listen to } \\
\text { others and respect different } \\
\text { points of view. } \\
\text { It shows positive reactions to } \\
\text { the behavior diversity of } \\
\text { children and the diversity of } \\
\text { address in this regard in line } \\
\text { with their diversity and } \\
\text { appreciates the distinction } \\
\text { therein. }\end{array}$ \\
\hline & $\begin{array}{l}\text { Children learn in a } \\
\text { fair environment }\end{array}$ & $\begin{array}{l}\text { Knows relationships between } \\
\text { people, and identifies how } \\
\text { people are incorporated or } \\
\text { excluded from perceived or } \\
\text { social environments. } \\
\text { Knows bias and the ability to } \\
\text { deal with mercy and kindness. } \\
\text { Make decisions and solve } \\
\text { problems in a manner that meets } \\
\text { their needs within specific } \\
\text { contexts. } \\
\text { Think critically about fair and } \\
\text { unfair behavior. } \\
\text { Understand and evaluate } \\
\text { identity formation methods. }\end{array}$ & $\begin{array}{l}\text { Listen carefully to children's } \\
\text { concerns and discuss diverse } \\
\text { perspectives on issues of } \\
\text { inclusion and exclusion, and fair } \\
\text { and unfair behavior. } \\
\text { Children engage in discussions } \\
\text { based on respect and equality. } \\
\text { Discuss with children how to } \\
\text { build and enhance a limited set } \\
\text { of identities for stereotypes. } \\
\text { It draws children's attention to } \\
\text { issues of equity related to them } \\
\text { in the world of early childhood } \\
\text { and society. }\end{array}$ \\
\hline & $\begin{array}{l}\text { Children respect their } \\
\text { social responsibilities } \\
\text { and the components } \\
\text { of the environment in } \\
\text { which they live }\end{array}$ & $\begin{array}{l}\text { Play is used to explore and } \\
\text { apply new ideas. } \\
\text { Others participate to solve } \\
\text { problems and contribute to } \\
\text { collective outcomes. } \\
\text { It explores the growing } \\
\text { knowledge and respect for the } \\
\text { natural and artificial } \\
\text { environment. } \\
\text { Realizes the relationship } \\
\text { between land, humans, plants, } \\
\text { and animals. }\end{array}$ & $\begin{array}{l}\text { It enables children to access } \\
\text { many natural resources in their } \\
\text { environment. } \\
\text { His respect, care, and } \\
\text { appreciation are shown as a } \\
\text { breeder of the natural } \\
\text { environment. } \\
\text { It provides ways for enabling } \\
\text { children to care for and learn } \\
\text { from nature. } \\
\text { Consider the nature of children's } \\
\text { communication with nature and }\end{array}$ \\
\hline
\end{tabular}




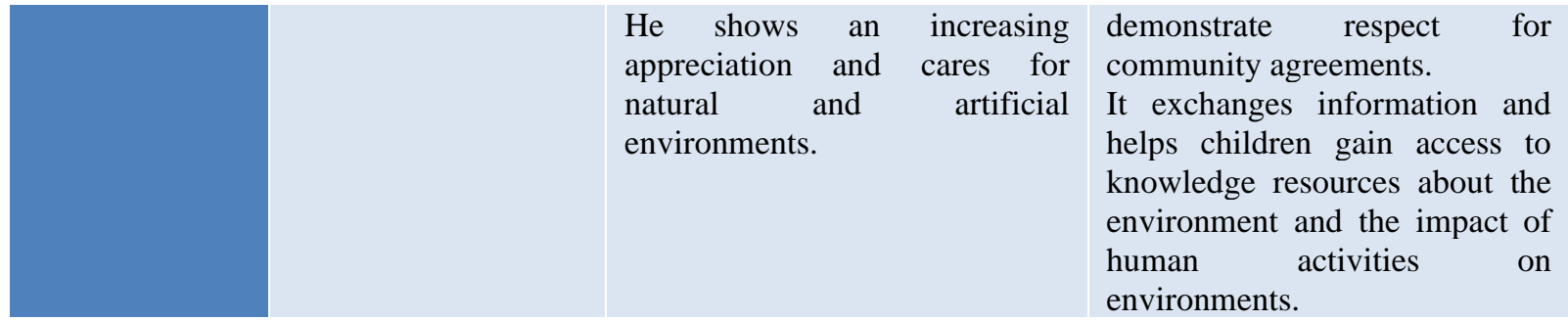

\subsection{The third result: children's sense of personal contentment}

Without a sense of personal contentment, it is challenging to develop a sense of the inherent presence of children and gain experiences that contribute to making their independent entity. Personal wellbeing includes good physical health, a sense of happiness, and successful social performance.

Attention must be paid to children's sense of personal contentment, according to providing trusting relationships, safe environments, respecting aspects of their development, appreciation of their cultural identity, and gently responding to their emotional state (State Library Victoria,2015).

Childhood professionals play individually and together with a key role with families in supporting children's feelings of personal contentment according to expressing and managing their feelings such as joy, sadness, frustration and fear, and seeking support from others around them. Their feelings and feelings of others are known and accepted, and seeking support from others for their opinions in line with their evolving capabilities.(Singer \& El-Sayed Mahmoud, 2020)

With increased physical mobility, a more significant opportunity is available to explore the world, manage and move their bodies in the space of their environments, learn to maintain their basic hygiene practices and maintain basic health and safety practices and manage their health with the healthy diet and exercises necessary for a healthy life.

When children play with other children, they create social groups, test ideas, and challenge the way others think. They ask questions and broaden their thinking and desire to learn. The inclusion of children in play makes play enable them to enjoy their own being (Lang, 1995), encourage cognitive curiosity, solve problems, cooperate with children, and draw positive ways to engage with others (Hunkin, 2014).

The outdoor play areas (in the open air) are a feature of a good learning environment that offers a wide range of play spaces in the natural environment (such as plants, trees, gardens, edible plants, sand, gravel, mud, and water). These spots encourage the spontaneity, risk-taking, exploration, discovery, contact with nature, respect the natural environment and develop the environmental awareness (State Library Victoria,2015).

For example, digital technology may enable children to access global resources and connections and encourage new ways of thinking. The environment can highlight the promotion of the child's concept of their responsibility to care for and preserve the environment (Hunkin, 2014).

Proper nutrition is essential for a healthy life that enables children to participate actively in play, and the childhood environment provides an opportunity to experience healthy foods and learn more about nutritional options, including preparing nutritious food, understanding aspects of an active lifestyle including positive experience for active outdoor play and physical exercise, avoiding substances or products that harm their health and wellbeing.

With physical activity and attention to large and fine motor skills, it gives children the foundations of independent growth and the conviction that they are able to do some tasks themselves ... for example dancing, drama and musical experiences can combine stillness and movement, and learn the children to build and implement simple rhythmic movement sequences (Elliott \& Young, 2015).

Through movement patterns and their dependence on their actions, they develop spatial awareness and the ability to move around in confidence and safety in their surroundings. It is also known that the growth of spatial awareness during the first years affects the development of children's athletic abilities positively.

For example, physical comfort contributes to children's ability to focus, collaborate, and learn. When children become more independent, they can take greater responsibility for their own health and hygiene, and they are able to take into account their own safety and that of others (Elliott \& Young, 2015).

The following table shows the indicators of feelings of personal contentment and the practices of the child and teachers to develop these indicators:

\begin{tabular}{|c|c|c|c|}
\hline Outcome & Indicators & Child practices & Teacher practices \\
\hline $\begin{array}{l}\text { Children's } \\
\text { sense } \\
\text { personal of } \\
\text { contentment }\end{array}$ & $\begin{array}{l}\text { Children have a strong } \\
\text { sense of social and } \\
\text { emotional contentment }\end{array}$ & $\begin{array}{l}\text { The child shows trust in others } \\
\text { and cooperating in an increasing } \\
\text { and integrated manner with } \\
\text { others. } \\
\text { Children participate others in }\end{array}$ & $\begin{array}{l}\text { Shows affection, } \\
\text { understanding, respect, and } \\
\text { cooperation for all children } \\
\text { and documents their } \\
\text { accomplishments rand }\end{array}$ \\
\hline
\end{tabular}




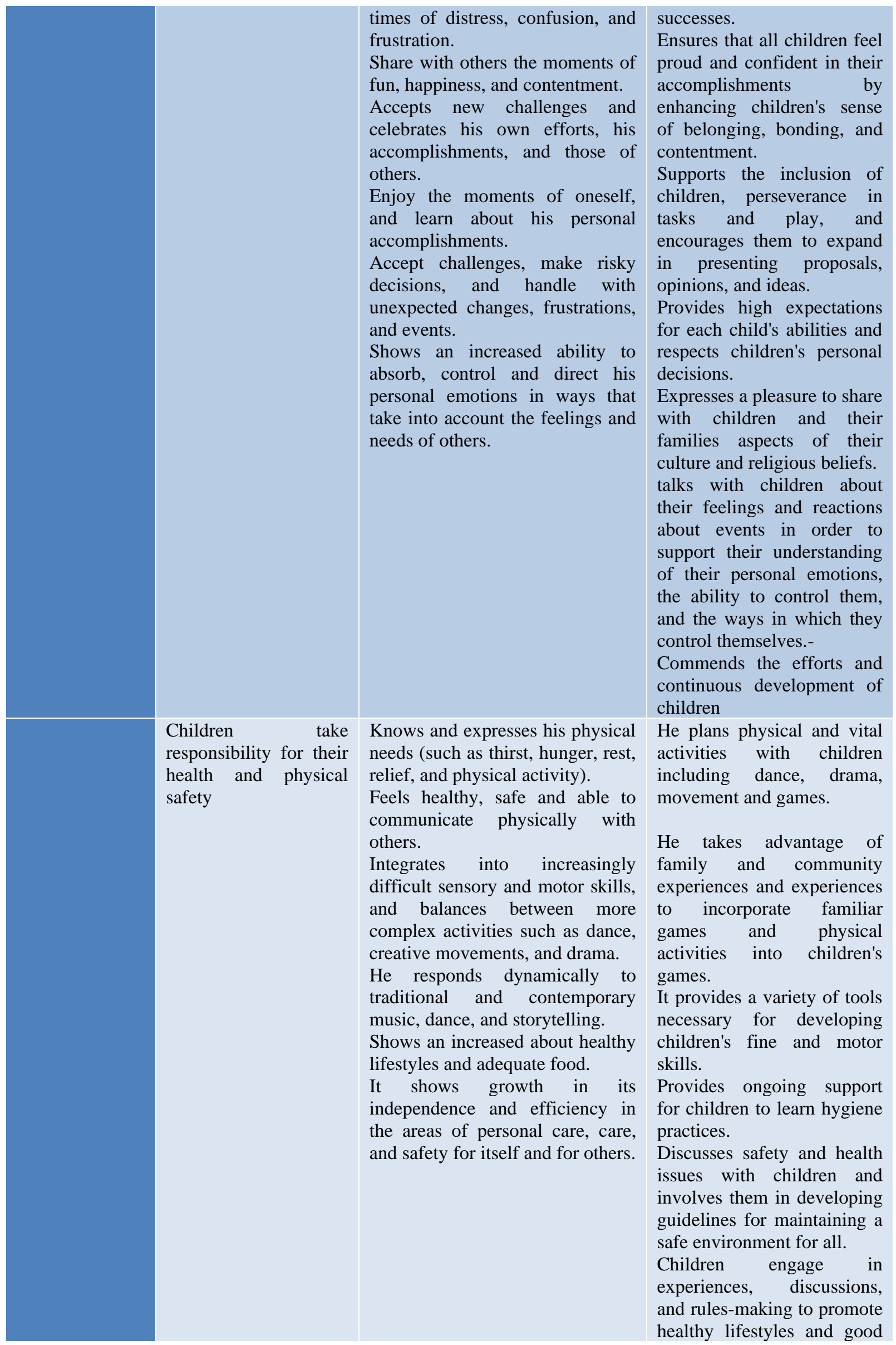




\subsection{Fourth result: Children self-confidence}

nutrition.

Responsive learning relationships support children with their curiosity and eagerness to learn and explore the world through touch, sight, sound, taste, smell and movement. Hence, this can give them more confidence to explore and experiment with new ideas, and more willingness to learn, trust and participate in lifelong learning. The child's brain develops through his active participation with others (Lansdown, 2004). With the warmth and support of others, children realize that learning is fun and useful. Normal playing time gives them an opportunity to discover, build confidence, confront the challenges and success in their learning and contribute positively to the learning of other children. In addition to generating new motives for learning, develop and employ their imagination, and build problem-solving and research skills. (Koga, Bennett \& Moss, 2010)

With encouragement, children become comfortable with taking risks, and they know that failure is a valuable part of learning and that learning from mistakes supports subsequent success and more growth in seeking help when they need it.

Children's participation in learning changes the things they know, can do and value. Moreover, when providing many opportunities and a rich supply of natural and manufactured materials and tools, children build, sculpt, and draw, and participate in sustainable joint talks that focus on their interests. (Elliott \& Young, 2015)

Children learn and expand their thinking skills when acquiring opportunities to generate questions about situations and phenomena, implement work paths, evaluate results, and ask questions from their imagination of this situation, which causes children to engage in their environment, share their feelings and thoughts about learning with others, and understand that listening to others' responses may help them to understand experiences and make them new. (Koga, Bennett \& Moss, 2010)

Children learn and expand their learning by communicating with people, places, technologies, and natural materials. They employ things in inquiring, innovating and building, and use their notes and others' comments to revise and build on the idea. (Elliot 2008)

Children take advantage of many opportunities to generate and discuss ideas, make plans, practice exercises, brainstorming, thinking, and give reasons for their choices. They research what they can do, systems, and how they work. Using information and communication technologies helps their thinking and represent what they know and understand. (Goleman, 2012)

Children use methods such as exploration, teamwork, and systematic solution to problems and develop behaviors such as curiosity, perseverance, and creativity that give them the inherent presence and benefit from learning. Confident children have the ability to adapt their past experiences and benefit from one context to another and to find and use resources in order to learn from one of the effective learning skills. (Lansdown, 2004)

In the supportive environment for learning, children are confident and involved. Their ability to assume the responsibilities of education, refine their personality and contribution in the relevant social environment increases, which makes learning clearer and increases children's sense of belonging, and encourages children to interact with learning methods. This can be noticed through the child's ability to deeply focus on all what draw the attention. Children see the world from different angles, have different learning methods and their preferred methods of learning. In addition, they find new knowledge through group practices and collaborative negotiation and these are essential skills for lifelong learning. (Lansdown, 2004)

The following table shows indicators of self-confidence and the practices of the child and teachers that develop or improve these indicators:

\begin{tabular}{l|l|l|l} 
Outcome & Indicators & Child practices & Teacher practices \\
\hline $\begin{array}{l}\text { Self- } \\
\text { confident } \\
\text { Children }\end{array}$ & $\begin{array}{l}\text { Children } \\
\text { develop } \\
\text { learning habits } \\
\text { such as } \\
\text { curiosity, } \\
\text { cooperation, } \\
\text { creativity, } \\
\text { perseverance } \\
\text { and appropriate } \\
\text { reactions }\end{array}$ & $\begin{array}{l}\text { Child's desire to learn more about } \\
\text { their environment, and use toys to } \\
\text { explore and visualize ideas and } \\
\text { verifying them. } \\
\text { Child expands and pursues their } \\
\text { special interests with enthusiasm, } \\
\text { strength and focus } \\
\text { Child creates experiences through } \\
\text { play and contributes to them with } \\
\text { their experiences arising out of pure } \\
\text { thinking }\end{array}$ & $\begin{array}{l}\text { Teacher recognizes the importance of } \\
\text { learning and provides a flexible and } \\
\text { open learning environment } \\
\text { Teacher responds to the aspects of } \\
\text { children's learning by responding to } \\
\text { them, encouraging them and providing } \\
\text { them with additional ideas } \\
\text { Teacher provides the right place and } \\
\text { time to integrate children in achieving } \\
\text { individual and shared goals }\end{array}$ \\
& $\begin{array}{l}\text { meaningful experiences that depend } \\
\text { on asking questions, affirming } \\
\text { creativity and producing new ideas } \\
\text { and methods. }\end{array}$ & $\begin{array}{l}\text { He listens carefully to the ideas of } \\
\text { children and discusses with them on } \\
\text { how to develop them, and provides } \\
\text { opportunities for them to reconsider } \\
\text { their ideas and expand their thinking }\end{array}$ \\
& & He uses ideal exploration processes
\end{tabular}




\begin{tabular}{|c|c|c|}
\hline & & $\begin{array}{l}\text { like curiosity imagination, and trying } \\
\text { to experiment with new ideas and } \\
\text { facing challenges } \\
\text { He discusses what they learned and } \\
\text { how they learned it }\end{array}$ \\
\hline $\begin{array}{l}\text { Children } \\
\text { develop a series } \\
\text { of skills and } \\
\text { methods such as } \\
\text { problem } \\
\text { solving, } \\
\text { inquiry, } \\
\text { research, } \\
\text { achievement, } \\
\text { and hypothesis }\end{array}$ & $\begin{array}{l}\text { Child uses a variety of thinking } \\
\text { strategies to deal with specific } \\
\text { situations and reuse these strategies } \\
\text { to suit new situations } \\
\text { Child uses mathematical notation to } \\
\text { organize and communicate } \\
\text { mathematical ideas and concepts } \\
\text { The child engages in daily activities } \\
\text { in the light of their natural context } \\
\text { and derives general laws from } \\
\text { them, by using patterns they have } \\
\text { created or identified themselves and } \\
\text { then explaining to others using } \\
\text { mathematical symbols }\end{array}$ & $\begin{array}{l}\text { He creates environment for Learning } \\
\text { with appropriate levels of challenge } \\
\text { encourages children to explore, } \\
\text { experiment and take appropriate risks } \\
\text { in their learning } \\
\text { Recognize mathematical concepts that } \\
\text { children bring to learn and build on } \\
\text { these concepts in ways that are } \\
\text { relevant to each child } \\
\text { He provides experiences that } \\
\text { encourage children to achieve and } \\
\text { solve problems } \\
\text { He encourages children to use } \\
\text { language to describe and explain their } \\
\text { ideas } \\
\text { He provides opportunities to share } \\
\text { experiences that support achievement } \\
\text { in complex ideas, concepts, logic, and } \\
\text { hypothesis } \\
\text { He encourages children to make their } \\
\text { ideas and theories visible to others }\end{array}$ \\
\hline $\begin{array}{l}\text { Children } \\
\text { transfer and } \\
\text { apply what they } \\
\text { have learned } \\
\text { from one } \\
\text { context to } \\
\text { another }\end{array}$ & $\begin{array}{l}\text { Child imitates and repeats other } \\
\text { people's practices and actions, } \\
\text { either directly or at a later time } \\
\text { There is a relationship between } \\
\text { experiences, concepts and processes } \\
\text { Child uses play and reasoning } \\
\text { processes to solve problems } \\
\text { Child applies generalizations from } \\
\text { one case to another } \\
\text { Children use strategies that were } \\
\text { effective in solving problems in one } \\
\text { case in a new context }\end{array}$ & $\begin{array}{l}\text { He Appreciates signs indicating that } \\
\text { children are applying learning in new } \\
\text { ways and talks to them about that in } \\
\text { ways that increase their understanding } \\
\text { He supports children to build multiple } \\
\text { solutions to problems and use different } \\
\text { ways of thinking } \\
\text { He draws children's attention to } \\
\text { patterns and relationships in the } \\
\text { environment and their learning } \\
\text { He establishes a time and spatial plan } \\
\text { so that children can thing about their } \\
\text { learning and see the similarities and } \\
\text { relationship between current and new } \\
\text { learning }\end{array}$ \\
\hline $\begin{array}{l}\text { Children derive } \\
\text { their own } \\
\text { learning by } \\
\text { communicating } \\
\text { with } \\
\text { individuals, } \\
\text { place, } \\
\text { technology, } \\
\text { natural and } \\
\text { unnatural } \\
\text { materials }\end{array}$ & $\begin{array}{l}\text { Child uses his senses to explore } \\
\text { natural environments and contexts } \\
\text { Child explores the Social } \\
\text { construction that contributes to } \\
\text { learning } \\
\text { Child uses environmental data, } \\
\text { media, sounds and drawings in his } \\
\text { social environment } \\
\text { Child employs resources to achieve } \\
\text { inherent presence, aggregation, } \\
\text { innovation and construction } \\
\text { Child Understands appropriate } \\
\text { techniques for his age, learning and } \\
\text { maturity, and uses information and } \\
\text { communication technology ICT in } \\
\text { order to solve problems, explore } \\
\text { ideas and theories. }\end{array}$ & $\begin{array}{l}\text { He provides opportunities and support } \\
\text { for children to integrate into beneficial } \\
\text { learning relationships } \\
\text { He provides tangible and exploratory } \\
\text { experiences with natural and unnatural } \\
\text { materials } \\
\text { He Builds relationships between early } \\
\text { childhood and community contexts } \\
\text { He thinks carefully about how children } \\
\text { are assembled for play, taking into } \\
\text { account the possibility of preparing } \\
\text { and enhancing peers } \\
\text { He provides appropriate tools, } \\
\text { technologies, skills, and knowledge to } \\
\text { enhance children's learning abilities } \\
\text { He provides opportunities for children } \\
\text { to socialize, such as a cooperative } \\
\text { learning strategy. }\end{array}$ \\
\hline
\end{tabular}


Dialogue is an important component of the inherent presence of children as they talk from birth with others using different gestures, sounds, language, and communication tools. They are social beings who exchange ideas, opinions, and feelings, and they use tools and means of communication, including music, dance, and acting to express themselves, communicate with others, and expand their learning. (Koga, Bennett \& Moss, 2010)

Since birth most children are social and eager to exchange ideas, questions, and feelings. They appear using gestures, movement, visual and non-verbal cues, sounds, language, and auxiliary communication to engage in the world and form relationships. This development needs to understand how symbols and patterns work and how they can be used to engage others. From birth, intentional communication is strengthened and expanded (Lally, 2005)

Children learn to exchange communications through their relationships with responding adults and explore patterns of sound, movement, singing, reading stories, playing games, and recording their thoughts.

Children's wellbeing, identity, and sense of will and their ability to make friends are closely related to developing dialogue skills, and are closely related to their ability to express feelings and ideas.

From birth, gestures for children are the beginning of efficient communication. Adults who spend time communicating from person to person with young children, speaking and talking to the child with multiple exchanges back and forth, make significant contributions to expanding the growth of children's vocabulary. (Hunkin, 2014)

Children are effective communicators, as the communication and self-expression take many forms, including sharing stories and symbols from their own culture, re-enacting well-known stories and using creative arts such as painting, sculpture, drama, dance, movement and music to communicate with others. They create and explore fantasy worlds through dramatic gameplay and artwork. They build great vocabulary, which is able to express ideas verbally and use a wide range of media. They recognize the function and value of the visual elements and use them to symbolize meaning, for example, using color in drawing to express emotions. Children begin to explore written communication by writing, drawing, and producing approximate writing estimates. They use digital technologies and multimedia resources to communicate, play, and learn. They create and display their private information in a way that suits audiences and different purposes. (Edwards, 2012)

Children use symbols to explore and play to represent and make sense. They become aware of the relationships between oral and visual notations and learn about patterns and relationships. They learn how to represent sounds alphabetically and to identify some of the sounds of letters, symbols, characters, and signs. While children continue to build their skills in reading printed text from left to right and from top to bottom (in English families), they use information in the context of images and other sources to help make sense. As they progress through this stage, children begin self-correction when reading aloud and distinguishing between texts that represent real and fictional experiences. (Uprichard, 2007)

Children learn and develop access to the environments rich with printing and communication with adults who design and respond to children's oral and written messages, which help to advance learning progress. Children are increasingly using traditional speech and writing, and simple punctuation marks. Over time, children learn to use and create simple texts on familiar topics and choose content, form, and vocabulary in their writing. As their skills advance, they spell frequently used words and use known spelling patterns to make reasonable attempts to spell unfamiliar words. (Koga, Bennett \& Moss, 2010)

Arithmetic is the ability to use calculations in daily life as children learn new mathematical concepts through daily interactions. It is essential for the mathematical ideas that young children interact with, to be relevant and meaningful in the context of their current lives. It requires teachers to have rich arithmetic vocabulary to describe and explain mathematical ideas accurately to children and to support mathematical growth.

Spatial awareness, pattern, counting, measurement, logic data and relationships, and exploring the world are allpowerful mathematical ideas that children need to be educated. (Bredekamp, 1987)

Experience in early childhood is based on linguistic experiences and literacy and numeracy education that are shaped by children within their families and communities, and that positive attitudes and competencies in literacy and numeracy are essential to successful children's learning. The foundations of these competencies are adopted in childhood. (Uprichard, 2007)

The following table shows indicators of effective dialogue with children and child and teacher practices that develop or improve these indicators:

\begin{tabular}{l|l|l|l} 
Outcome & Indicators & Child practices & Teacher practices \\
\hline $\begin{array}{l}\text { Children are } \\
\text { good }\end{array}$ & $\begin{array}{l}\text { The child } \\
\text { interlocutors }\end{array}$ & $\begin{array}{l}\text { Child has funny interactions } \\
\text { using verbal and non-verbal }\end{array}$ & $\begin{array}{l}\text { He incorporates the child in funny } \\
\text { interactions with other children }\end{array}$ \\
& $\begin{array}{l}\text { verbally and } \\
\text { non-verbally } \\
\text { with others }\end{array}$ & $\begin{array}{l}\text { language. Verbally and non- } \\
\text { verbally respond to what he } \\
\text { sees, hears, touches, feels and }\end{array}$ & $\begin{array}{l}\text { He appropriately responds to } \\
\text { children's efforts }\end{array}$ \\
\hline He listens and responds to children's
\end{tabular}




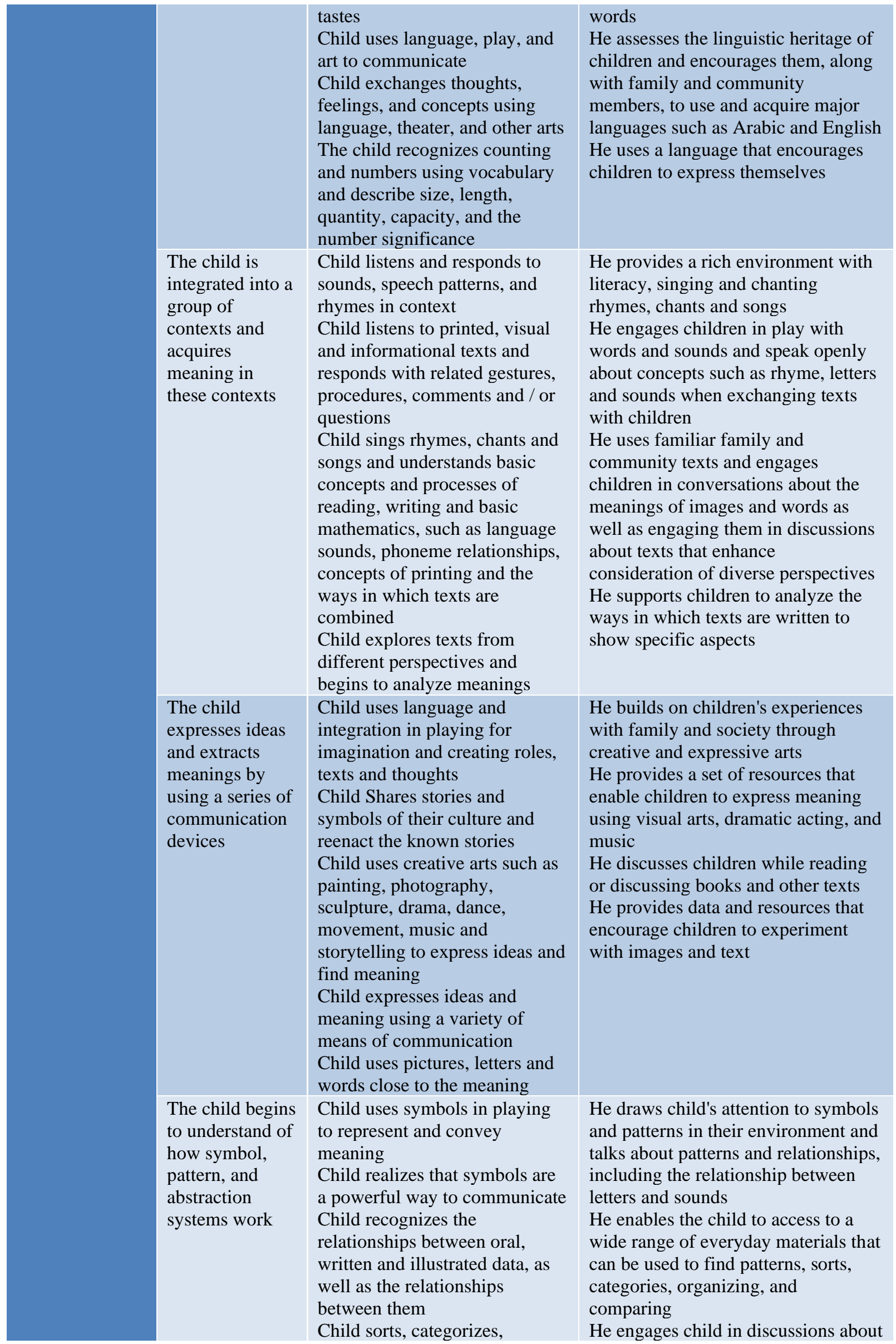




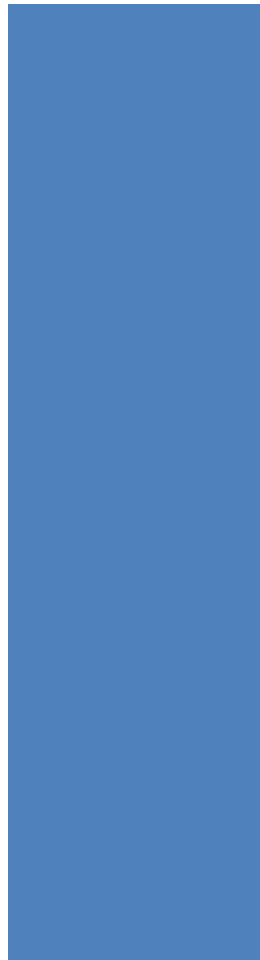

organizes, and compares events and attributes of things and materials, in their social and natural contexts

Child listens and responds to voices and patterns of speech, stories and rhyme Child depends on the sequence memory to complete the task

\section{Children use \\ Child learns about the uses of} information and communication technology to access information technology in everyday life and uses real or imaginary technology as pillars while playing

Child uses ICTs to access images and information, explore diverse perspectives and find meaning for his world and contexts

Child uses ICTs as tools for designing, drawing, editing, expressing and composing Child uses technology to enjoy and find meaning symbol systems, for example, letters and numbers, time, money, and musical notes

He enables the child to access to a wide range of technology He integrates technology into children's games experiences and projects

He teaches the child skills and techniques and encourages him to use technology to explore new information and represent his ideas He encourages collaborative learning about and through technology. This is among children and between the child and the teacher

\section{CONCLUSION AND DISCUSSION}

The fundamentals of the children's inherent presence are rooted in a strong sense of self identity and children's attachment to their context. Their sense of personal contentment, self-confidence, and good dialogue with them are in light of the standards, indicators and practices of the child, the teacher and everyone involved in dealing with the child.

Despite the progress in the movement to achieve the inherent presence of children since the adoption of the Convention on the Rights of the Child, this movement is still at early stage of its development. There is an urgent need to focus on more investment in the "institutionalization" of the inherent presence of children through cultural development and in effecting cultural changes related to the status and role of children, in order to achieve the full and sustainable realization of their rights, according to the following directions:

5.1 Issuing the necessary legislation to protect and develop children's rights, such as the mechanisms of eligibility, to be heard in families and schools and to protect them from all forms of violence, abuse and neglect.

5.2 Providing appropriate and accessible information on the rights of children of all ages. Since children can only exercise their rights if they have access to information in a form that they can understand and use.

5.3 Providing information, capacity building, democratic education, developing cooperative and child-friendly public services and institutions supporting children, peer education, making the media available, mobilizing the local community, and engaging in dialogues with the government in all relevant aspects of policy development.

5.4 Improving the quality of programs and initiatives aimed at developing the inherent precense of children according to ethical, sensitive and child-related standards that are comprehensive, safe, understandable and well received within the context of their families and societies.

5.5 Community networking of plans, programs and projects directed to support the inherent presence of children: establishing and strengthening communication links, building bridges of cooperation and participation between different institutions, exchanging experiences and benefiting from the expected initiatives and creations. Hence, facilitating the building of programs and projects aimed at expanding the level of participation at the community level in terms of quantity and deepening its positive impact "in terms of quality".

5.6 They are developing a culture of respect for the right of children to express their views and take them seriously. The implementation of this standard is a prerequisite for paving good and fertile soil from which the fruits of participation sprout and the foundations of sustainability for the flowering take root, in addition to enriching the culture with positive values and trends, and with knowledge and conscience in enhancing the skills and competencies of the inherent presence, and in covering this cultural enrichment for both adult and children's culture.

5.7 Creating a healthy environment for children: It is not less likely that childhood issues and children's rights receive indifference or even prevention or aggravation in various forms and for various reasons in many societies. The root of this error lies in the existence of cultural barriers between the adult and young community, and mutual cultural expectations between adults and children. 
These barriers and expectations are fed by a lack of understanding and awareness, the prevalence of negative ideas, beliefs, and attitudes towards children, which entails a circle of divergence or even dissonance between the worlds of adults and children. This is an important societal issue focusing on the efforts directed at addressing the knowledge distortion of children that may be tainted by adults, cognitive reconstruction, changing attitudes towards children, and lobbying to create a psycho-cultural environment friendly to children.

\section{RECOMMENDATIONS AND STUDY FORWARD}

The research ended with the importance of activating the fundamentals of the inherent presence of children in society by focusing on the following results and activating the role of the child and the role of the early childhood specialists and teachers.

- $\quad$ Developing a strong sense of identity for children

- Developing children's association and participation in their world

- $\quad$ Improving children's feeling of personal bliss

- Developing and improving children self-confidence

- Developing and enhancing effective dialogue with children.

\section{References}

1. Bouchard, C., Bigras, N., Cantin, G., Coutu, S., Blain-Brière, B., \& Eryasa, J. et al. (2009). Early Childhood Educators' Use of Language-Support Practices with 4-Year-Old Children in Child Care Centers. Early Childhood Education Journal, 37(5), 371-379.https://doi.org/10.1007/s10643-009-03557

2. Bradshaw, J., Hoelscher, P. and Richardson, D. (2007), 'An Index of Child Well-being in the European Union ', Social Indicators Research 80: 133-77

3. Bredekamp, S. (1987). Developmentally Appropriate Practice in Early Childhood Programs Serving Children from Birth through age Eight. Washington, DC: National Association for the Education of Young Children.

4. Corsin-Jimenez, A. (2007) Culture and Well-Being: Anthropological Approaches to Freedom and Political Ethics, UK: Pluto Press

5. Edgar, D., \& Edgar, P. (2008). Television, Digital Media and Children's Learning. Retrieved 9 May 2020 , from https://www.education.vic.gov.au/Documents/childhood/providers/edcare/veyldframework.pdf.

6. Edwards, A. (2012). The role of common knowledge in achieving collaboration across practices. Learning, Culture And Social Interaction, 1(1), 22-32. https://doi.org/10.1016/j.lcsi.2012.03.003

7. Edwards, S., \& Cutter-Mackenzie, A. (2011). Environmentalising Early Childhood Education Curriculum through Pedagogies of Play. Australasian Journal Of Early Childhood, 36(1), 51-59. https://doi.org/10.1177/183693911103600109

8. Elliott, S. (2008). The outdoor playspace naturally for children birth to five years. Pademelon Press.

9. Elliott, S., \& Young, T. (2015). Nature by Default in Early Childhood Education for Sustainability. Australian Journal Of Environmental Education, 32(1), 57-64. https://doi.org/10.1017/aee.2015.44

10. Evangelou, M., Brooks, G., \& Smith, S. (2007). The Birth to School Study: evidence on the effectiveness of PEEP, an early intervention for children at risk of educational under-achievement. Oxford Review Of Education, 33(5), 581-609. https://doi.org/10.1080/03054980701476477

11. Goleman, D. (2012). Emotional Intelligence. Random House Publishing Group.

12. Hill, N., \& Taylor, L. (2004). Parental School Involvement and Children's Academic Achievement. Current Directions In Psychological Science, 13(4), 161-164. https://doi.org/10.1111/j.09637214.2004.00298.x

13. Hunkin, E. (2014). We're Offering True Play-Based Learning: Teacher Perspectives on Educational Dis/Continuity in the Early Years. Australasian Journal Of Early Childhood, 39(2), 3035.https://doi.org/10.1177/183693911403900205

14. Ishimine, K., \& Tayler, C. (2013). Assessing Quality in Early Childhood Education and Care. European Journal Of Education, 49(2), 272-290. https://doi.org/10.1111/ejed.12043

15. James, A. (1993). Childhood identities. EDINBURGH University Press.

16. Joos, K. (2003). What does it mean to be a success?. Ufdc.ufl.edu. Retrieved 14 April 2020, from https://ufdc.ufl.edu/AA00020966/00001.

17. Koga, Y., Bennett, J., \& Moss, P. (2010). Caring and learning together: A cross-national study of integration of early childhood care and education within education. UNESCO, Paris. 
18. Lally, J. (2005). The Human Rights of Infants and Toddlers: A Comparison of Child-Care Philosophies in Europe, Australia, New Zealand, and the United States.. Eric.ed.gov. Retrieved 17 February 2020, from https://eric.ed.gov/?id=EJ847182.

19. Lang, P. (1995). Preparing Teachers for Pastoral Care and Personal and Social Education: To Train or Educate?. Pastoral Care In Education, 13(4), 18-23.https://doi.org/10.1080/02643949509470939

20. Lansdown, G. (2004). Implementing Child Rights in Early Childhood. Unicef.org. Retrieved 9 May 2020, from https://www.unicef.org/earlychildhood/files/Guide_to_GC7.pdf

21. O'Toole, L. (2014). Well-being as Wholeness: The perspective, process, and practice of Learning for Well-being. In Improving the Quality of Childhood in Europe (5th ed.). Alliance for Childhood European Network Foundation. Retrieved 29 March 2020, from https://www.learningforwellbeing.org/wp-content/uploads/QoC-Book-4-Chapter-2-Well-being-asWholeness-QoC-V4-Ch02.pdf

22. Pollard, E., \& Lee, P. (2003). Social Indicators Research, 61(1), 5978.https://doi.org/10.1023/a:1021284215801

23. State Liberty VICTORIA. (2015). Reading and literacy for all: QUALITY INDICATORS FOR EARLY YEARS LITERACY PROGRAMS IN VICTORIAN PUBLIC LIBRARIES. https://www.slv.vic.gov.au. $\quad$ Retrieved $18 \quad$ April $\quad 2020, \quad$ from https://www.slv.vic.gov.au/sites/default/files/Reading-and-literacy-for-all-early-years.pdf.

24. Shonkoff, J., \& Meisels, S. (2011). Handbook of early childhood intervention. Cambridge University Press.

25. Singer, N (2019). A Proposed Program for the Activities of the School Media Literacy in the Development of Some Dimensions of Learning for Students in the Third-Grade Primary Considering the Vision of Egypt 2030., International Journal of Humanities and Social Science Vol. 9 • No. 3 • March 2019.https://doi.org/10.30845/ijhss.v9n3p11

26. Singer, N. (2019). The relationship between watching animated cartoon and information processing speed and level for sample children in age group [5-6] years. Humanities \& Social Sciences Reviews, 7(5), 1321-1337. https://doi.org/10.18510/hssr.2019.75171

27. Singer, N., \& El-Sayed Mahmoud, E. (2020). Motives of the egyptian education future for sustainable development: a comparative analysis between 2020 and 2030. Humanities \& social sciences reviews, 8(2), 01-28. https://doi.org/10.18510/hssr.2020.82e01

28. Singer, N., Mahmood, E. A., \& Elsaeed, K. (2019). Entrepreneurship Culture In Education Institutions: Future Practices And Aspirations.Humanities \& Social Sciences Reviews, 7(1), 450-460. https://doi.org/10.18510/hssr.2019.7151

29. Sointu, E. (2005). The Rise of an Ideal: Tracing Changing Discourses of Wellbeing. The Sociological Review, 53(2), 255-274.https://doi.org/10.1111/j.1467-954x.2005.00513.x

30. Stamopoulos, E. (2012). Reframing early childhood leadership. Australasian Journal Of Early Childhood, 37(2), 42-48. https://doi.org/10.1177/183693911203700207

31. UNCRC. (1989). UN Convention on the Rights of the Child (UNCRC) - Unicef UK. Unicef UK. Retrieved 23 May 2020, from https://downloads.unicef.org.uk/wp-content/uploads/2016/08/unicefconvention-rights-child-uncrc.pdf.

32. Uprichard, E. (2008). Children as 'Being and Becomings': Children, Childhood and Temporality. Children \& Society, 22(4), 303-313. https://doi.org/10.1111/j.1099-0860.2007.00110.x 